\title{
THE IMPACT OF POST-MERGER CROSS-SHAREHOLDINGS ON South African Merger CONTROL POLICY ${ }^{1}$
}

\author{
Chris Charter
}

Cliffe Dekker Incorporated

\begin{abstract}
There is a concentration of EU and US standards in the South African economy. In addition, a number of large industries have been undergoing consolidation. As a result, the phenomenon of cross-holdings, both within and across industries, is not unusual.

In cases where the level of cross-holding falls short of joint control, the competition authorities have at times sought to apply the co-ordinated effects doctrine or some variation thereof hoping to lessen potential competition. More recently, the Tribunal has also considered the possible unilateral effects of the acquisition of a minority stake in a rival.

A number of cases has emerged that to a greater or lesser degree explores the impact of crossholdings and cross-directorships on the competitive behaviour of the firms concerned. This paper includes a review of some of these decisions with a view to determining whether any clear policy seems likely to emerge from the competition authorities.

The authorities' approach to date, reveals an evolution from reflex suspicion to a more reasoned, fact-based outlook. Cross-holdings and directorships are treated in the same way as any other evidence relevant to an analysis of a given merger.

However, despite the Tribunal's willingness to wrestle with various economic theories, the most recent decision suggests that the acquisition of a non-controlling cross-holding in a company may not fall under the analysis of South African merger regulation at all. Should that position change, following clarification by the Tribunal or an unequivocal ruling of the Competition Appeal Court, the body of case law goes some way to indicating the type and manner of analysis the authorities will employ.
\end{abstract}

Abstract

JEL G34, L41

\section{1}

\section{Introduction and legal background}

Section 12A of the Competition Act, 1998 ("the Act") sets out the methodology to be applied by competition authorities in consideration of mergers. For the present purposes, the relevant provisions are as follows:

\section{Section 12A. Consideration of mergers}

(1) Whenever required to consider a merger, the Competition Commission or Competition Tribunal must initially determine whether or not the merger is likely to substantially prevent or lessen competition, by assessing the factors set out in subsection (2)
(2) When determining whether or not a merger is likely to substantially prevent or lessen competition, the Competition Commission or Competition Tribunal must assess the strength of competition in the relevant market, and the probability that the firms in the market after the merger will behave competitively or co-operatively, taking into account any factor that is relevant to competition in that market...

In analysing mergers in accordance with the above provisions, there are generally two main types of anti-competitive effects that need to be dealt with, they are - 
- whether the merger will allow the merged entity to exercise a greater degree of market power, thereby allowing it to act independently of its customers, suppliers and, in particular, competitors, in raising prices or restricting output (so-called "unilateral effects"); or

- whether the merger would propagate an environment where the merged entity and its competitors are more likely to collude, ultimately resulting in higher prices (socalled "coordinated effects"). ${ }^{2}$

In assessing unilateral effects, the point of departure is generally to consider pre- and post-merger market shares as an indication of whether the merger is likely to create an entity with a disproportionately high market share. ${ }^{3}$ Where the relevant market remains contested by a number of players (or there is no change in concentration) then the merged entity is unlikely to be in a position to wield market power on its own.

However, the merger may nevertheless create or enhance conditions in the market which are conducive to collusion. In many ways, collusive conduct is of greater concern to competition authorities than single firm dominance. This is not only because such conduct often results in the most egregious of anti-competitive outcomes such as price-fixing or market allocation, but also because of the inherent difficulty in detecting and policing conduct between competitors that is practised subtly if not entirely tacitly. To put it crudely, unilateral conduct by a dominant firm can be dealt with relatively cleanly through amputation, while an industry beset by collusion amounts to a cancer which is far more difficult to isolate and treat.

Of course, in many instances, the same factors which give rise to concerns about unilateral effects also facilitate collusion. For instance, a merger which removes an effective or maverick competitor may make it easier for the remaining players to come to agreement on competitive issues, while at the same time making the merged firm more powerful in its own right. Similarly, a merger resulting in vertical integration may give the acquirer significant advantage over its non-integrated competitors, but may also assist

in information exchange thereby facilitating collusion.

Until the Primedia case discussed below, the focus of the competition authorities has been on the extent to which certain factors (cross holdings in particular) may give rise to collusion where there is no finding of negative unilateral effects. ${ }^{4}$ Following the Primedia case, an economic theory of unilateral effects arising out of cross-holdings has also been posited.

2

\section{Theory of harm}

Although the intention of this paper is to focus on the assessment of cross-holdings, it is worthwhile to briefly set out the economic basis for positing a theory of collusion.

Collusion ultimately requires the resolution of a competitive tension - often referred to as the "incentive constraint" or "cartel problem". Simply put: competitors have an inherent incentive to deviate from collusive action (e.g. by charging less than the collusive price) as this should result in increased sales and thus greater profits. In order for the collusion to remain intact, competitors need to believe that the immediate gain realised after a deviation will be outweighed by profits lost when (and if) competitors react (e.g. by reducing prices in turn, which then need to be matched in order to remain competitive).

If it is accepted that any collusive situation naturally gives rise to the temptation to cheat and therefore break the collusion, then it becomes necessary to identify certain elements that should be present in order to counter such temptation.

- Firstly, the market must be sufficiently transparent in order that participants can readily detect a deviation.

- Secondly, there must be an apprehension that deviation will be credibly punished (e.g. through aggressive market behaviour by other firms). The punishment should be such that profits will ultimately be diminished by more than the short term gains realised immediately following the deviation. 
- Thirdly, the structure of the market should be such that collusion is feasible. If a substantial number of firms does not follow a coordinated strategy, then it would not be profitable for the remaining firms to align prices or output as this would be undermined by the behaviour of the nonparticipating firms. ${ }^{5}$

In principle, parties to a collusive strategy need not in actual fact communicate with one another or reach an express agreement. Where the market is sufficiently transparent for deviations to be identified with alacrity and if retribution is likely and credible, then tacit collusion may arise with attendant anticompetitive effects.

However, such "conscious parallelism" can be an inefficient means of reducing competition, as merely watching the market can result in mistakes or settling for sub-optimal pricing and output strategies. These are difficult to change without upsetting the delicate balance required to overcome the cartel problem. It would be far more effective for firms to actually communicate with each other or to exchange market information which would allow them to set prices that maximise profits. It is in this milieu that mere (tacit) coordination moves towards collusion. It stands to reason that while tacit coordination may be of some concern to competition regulators, overt collusion is a complete anathema.

Against the above backdrop, legal and academic authorities over the world have sought to further identify certain more specific factors which, depending on their presence in a given market structure, are likely to facilitate or deter collusion. Such factors include the levels of concentration, barriers to entry, countervailing power, product homogeneity, levels of demand and capacity and others. ${ }^{6}$ One such factor that is often of concern is the presence of structural links between competitors, such as crossownership.

In essence, the theory is that such structural links, although falling short of actual control or ownership, make it easier for the linked firms to co-ordinate their action. Motta ${ }^{7}$ states as follows:
"First and more obvious, if a representative of a firm is sitting in the board of directors of a rival firm, it will be easier to coordinate pricing and marketing policies. It might also be easier to exchange information on the marketing and pricing policies, which makes it easy to monitor a rival's behaviour... and is an important facilitating factor for collusion. Second, even if a firm did not have any say in the business policies of the other, but just owned a share of it without representation on the board, the incentives to compete in the marketplace might be reduced. This is because the profits of the rival firm would affect the firm's own financial performance, composed of market profits and financial returns: an aggressive market strategy (like a deviation from a collusive price) would be less profitable than if there were no stake in the rival firm, because it would decrease the returns on financial investments." (Motta, 2004: 144)

Accordingly, cross-holdings and crossdirectorships contain both necessary elements of transparency (through access to or exchange of competitively sensitive information) and punishment (in the form of reduced financial returns) required for collusion. Furthermore, board and shareholders' meetings provide a forum for active coordination.

Motta goes on to state that "Overall, it would therefore seem wise not to allow a firm to have a minority shareholding in a competitor". (Motta, 2004: 144)

In the context of cross-directorships, a similar view is manifest in Section 8 of the Clayton Act in the USA, where interlocking directorships between rival firms (over a threshold) are prohibited outright.

Although the South African Competition Act contains no express prohibition on crossdirectorships or cross-shareholdings, the possible anti-competitive consequences of such a set-up is given express legislative attention (albeit in the context of prohibited practice) in section 4(2) the Act. This provides that an agreement to engage in cartel behavior is presumed to exist between two or more firms if any one of those firms owns a significant interest in the other, 
or they have at least one director or substantial shareholder in common. ${ }^{8}$

The question this paper seeks to explore is what is the current attitude of competition authorities to post merger interlocks between firms. Although examination of the likely coordination effects of mergers is standard practice, there are relatively few cases that deal specifically with the question of cross shareholdings and cross directorships. Nevertheless, there is evidence of evolution in approach in the cases.

\section{3}

\section{The distinction between cross- holdings and cross-directorships}

In principle, it is possible for cross-directorships to occur without any concomitant shareholding. However, in the context of merger analysis, it is generally the acquisition of a substantial shareholding that gives rise to the right to appoint a director to the board of the target firm. In the past the impact of cross-directorships was considered as part of the more general enquiry of the competitive effects of the cross-holding. To a degree, this has had the effect of conflating cross-directorships with cross-holdings.

It follows that cross-directorships are often viewed by the authorities as the manifestation of the apprehension of coordination that may arise when two rivals have a common shareholder. Perhaps for this reason, the authorities have attempted to address such an apprehension by seeking to eliminate cross-directorships rather than cross-holdings. As emerges from certain of the decisions discussed below, this often fails to appreciate the nature of board representation and also tends to underplay the role of shareholders and other management in determining the competitive policy of the firms in question.

\section{4}

\section{Some South African case law}

\section{Momentum Group Ltd / African Life Health (Pty) $\mathrm{Ltd}^{9}$}

The first time the Tribunal was called upon to specifically address the question of cross directorships in a merger context was in 2006, when Momentum and African Life Health ("ALH") sought approval for a merger that, on the face of it, was relatively innocuous in that it resulted in a mere 3 per cent accretion of market share in the relevant medical administration market.

Whilst the Commission recommended an unconditional approval of the merger, the Tribunal became somewhat fixated with the fact that First Rand, the ultimate controller of the merged entity (Momentum) also controlled Discovery Health, another major player in the industry. This fact was not controversial, and the Tribunal had previously approved the merger in terms of which this group set-up was achieved. The Tribunal also accepted evidence of the parties that Discovery and Momentum (currently within the First Rand Group) were encouraged to and in fact did compete vigorously.

However, what became a concern to the Tribunal in the ALH transaction was whether such levels of competition would be sustained in the light of an apparent strategic shift whereby players like Momentum and Discovery were both seeking to expand into the low-income market. High growth opportunities were perceived here, coupled with the fact that the industry as a whole had been in a process of consolidation. In the Tribunal's reasoning, the ALH acquisition was the strategic impetus required for Momentum to enter the growth market. It was concerned that competition may be threatened as a result of Discovery and Momentum sharing the same parent which may enable them to "behave strategically". In the Tribunal's own words:

"It is therefore imperative to maintain the rivalry between these two entities and the concern raised by this merger would be that post-merger there would be an enhanced incentive to co-ordination, rather than rivalry." 10

Having previously approved a merger whereby Discovery and Momentum came to be controlled by First Rand, the Tribunal could hardly now suggest that one of these two entities be sold, particularly in light of the fact that the transaction under scrutiny did not much change 
the combined market shares of the two large competitors. Instead, it appears as if the Tribunal sought to ensure that any attempt by First Rand to coordinate the conduct of the two medical aid companies would be made more difficult. It therefore imposed a condition requiring two common non-executive directors of First Rand who were appointed to the boards of Momentum and Discovery to resign. First Rand was also required to ensure that in the future, no common directors were appointed to the boards of Momentum and Discovery, at both operational and holding company level.

It is worth noting that the Tribunal apparently did not seek to prevent First Rand from appointing directors to each of the Momentum and Discovery groups, but merely required that such directors not be the same person. ${ }^{11}$ It therefore appears that in this case, the Tribunal understood "cross-directorship" to refer to directorship by the same individual on the boards of two competing companies.

\section{Momentum Group Ltd and others v The Chairperson Competition Tribunal and others $^{12}$}

This case followed closely on the heels of the first Momentum decision, being an appeal to the Competition Appeal Court against the condition imposed by the Tribunal in the first instance.

In upholding the appeal, the CAC criticised the Tribunal inter alia for its statement quoted above, namely that the merger created "an enhanced incentive to coordination rather than rivalry", which the CAC felt was unsupported by evidence and furthermore not borne out by the probabilities. Even if the convergence of the two groups were a notional possibility, the CAC pointed out that the mechanisms in place for this to occur (i.e. the fact that Discovery and Momentum exist together as part of the First Rand group and the cross-directorships between them) existed prior to the merger and do not arise as a result thereof. The fact that this state of affairs had been previously approved meant that the Tribunal could not base a finding of future lessening of competition on the combination of the Momentum and Discovery interests per se. Instead they would have to find that the 3.3 per cent increase in the aggregated market share within the First Rand group would somehow tip the scale against competition in the market. According to the CAC, such a finding was not supportable on the evidence.

The CAC also tended to support the notion that while cross-directorships at operating level may be more likely to facilitate the exchange of sensitive information, at holding company level this was less apparent.

Finally, the CAC remarked "that the conditions impose no real safeguard for competition. Cross-directorships are prohibited without restricting the attendance of non-directors at board meetings." 13 Although the CAC did not say so expressly, the controversy is whether the concern should be with common directors (who may indeed be appointed by otherwise unrelated competitors) or whether the same coordination could be achieved through different directors appointed by a common party. It is submitted that in principle, both manifestations may be of concern, although it is to be noted that the former scenario may occur even where there is no common shareholding.

Although it is tempting to see the CAC decision as substantially raising the burden of proof for the competition authorities to allege enhanced co-ordinated effects based on cross-directorships and crossshareholdings, one should be cautious not to lose sight of the specific facts of the matter. It is submitted that the decision should be seen in the context of peculiar evidence as to First Rand's investment policy (in terms of which it cultivated an "owner manager" ethos whereby management of subsidiaries are given the freedom to set and pursue goals within a broad corporate governance framework). The crossdirectorship accrued to a financial investment company, would mean that generic and high level investment information is of more interest to it than operational issues which are entrusted to executives with no link to First Rand. In addition and as discussed above, the structural links that the Tribunal found worrisome were historical and did not arise as a result of the merger. 
Main Street 333 (Pty) Ltd / Kumba Resources $\operatorname{Ltd}^{14}$

Following the CAC's reversal of the Tribunal's charge against cross-directorships in the Momentum case, the Tribunal had a further opportunity to consider the issue in a case where the Commission concluded that post-merger cross-directorships, arising out of a crossholding, should be removed.

Kumba Resources Limited ("Kumba") contained the unbundled mining activities of Iscor Limited (now ArcelorMittal South Africa). Controlled ${ }^{15}$ by Anglo American ("Anglo"), Kumba's mining activities consisted of iron ore (through Sishen Iron Ore Company - "SIOC") coal (through Kumba Coal) base metals (through Kumba Base Metals) and heavy minerals (through Ticor).

For various reasons, Anglo determined to split out Kumba's iron ore business from its other mining assets, the former to be retained by Anglo and the latter to be transferred to a newly created black-owned, listed resource company, Exarro Limited ("Exarro"). Anglo would retain a 17 per cent interest in Exarro directly and enjoy one seat on the Exarro board.

Exarro would be controlled, via the interposition of a further investment vehicle ${ }^{16}$, by Eyesizwe SPV, in which parties like Anglo and BHP Biliton ("BHP") would hold 11 per cent and 9 per cent respectively of the equity interest and would each be entitled to appoint a director to the board.

Immediately prior to the transaction, Anglo and BHP held 11 per cent and 9 per cent respectively in Eyesizwe Coal, which entitled each of them to a seat on the board. As part of the transaction, Eyesizwe Coal would be transferred to Exarro. Although Anglo and BHP's interest in Eyesizwe SPV mirrored that held in Eyesizwe Coal, it is worth noting that these interests were now three times removed, as Eyesizwe SPV, BEE Holdco and Exarro now stood between Anglo and BHP, and Eyesizwe Coal.

Ultimately, Exarro would house the coal, heavy minerals and base metals operations of Kumba, the coal mining interests of Eyesizwe Mining as well as a 20 per cent interest in SIOC.

Given Exarro's fledgling status in a difficult industry, Anglo sought to remain associated with the project, ${ }^{17}$ as reflected by its minority interest and board representation (in the operating company as well as at shareholder level).

The post merger ownership structure was presented as follows: 


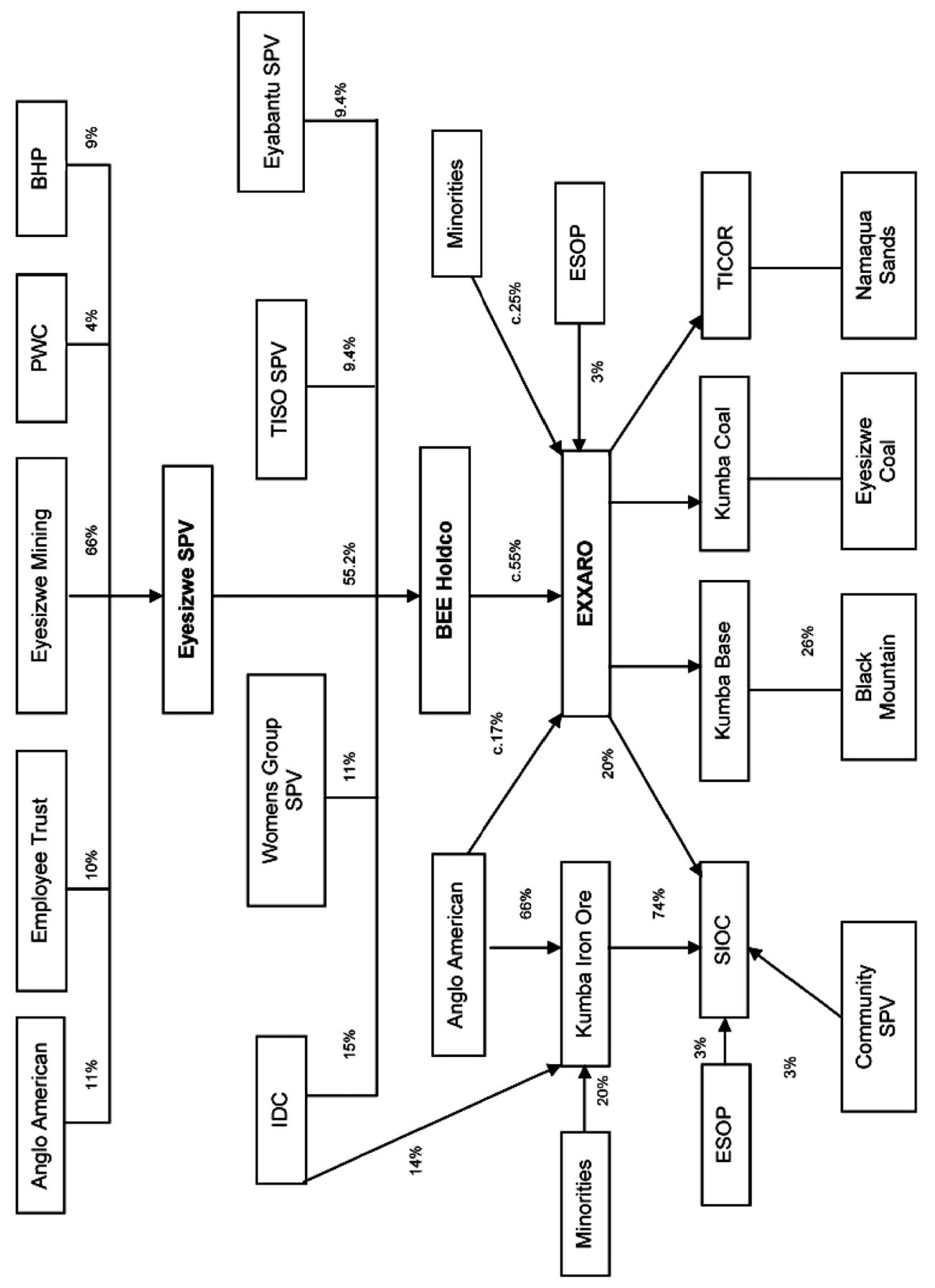


At a horizontal level, the analysis turned on the market for bituminous thermal coal, ${ }^{18}$ which, pre merger, was produced in various quantities by each of Kumba, Anglo ${ }^{19}$ and Eyesizwe. The post merger combination of the coal assets of Kumba/Anglo and Eyesizwe gave rise to a 5 per cent increment in market share, which the Tribunal found would not substantially lessen competition in the supply of thermal coal.

Unilateral effects thus disposed of, the Commission was nevertheless concerned that because Anglo was permitted to appoint a director to the Exarro board and to the Eyesizwe SPV board, this would provide the opportunity for an exchange of commercially sensitive information that would facilitate coordination in the thermal coal market, mainly as a result of Anglo's ownership of Anglo Coal, a competitor of Exarro. The Commission therefore recommended that such representations be prohibited as a condition to the merger approval.

In contradistinction to its previous pronouncements on the subject, the Tribunal took considerable pains to trawl through and quote various international authorities on the issue of co-ordinated effects. At paragraph 37 of the judgement, the Tribunal summarised the position as follows:

According to international practice, a merger may give rise to coordinated effects concerns in two instances. In the first instance, it can strengthen an existing coordination. In this instance there would need to be evidence of an existing coordination, and secondly, that the merger is likely to strengthen that coordination. The second instance is that the merger increases the likelihood that firms will coordinate. Here there may be no evidence of an existing coordination, but evidence that post merger, it will be probable.

The Tribunal found that such an approach resonated rather well with the top-notes of section $12 \mathrm{~A}$, which, as indicated above, requires a finding as to the "probability that the firms in the market after the merger will behave competitively or cooperatively, taking into account any factor that is relevant to competition in the market including. . . the history of collusion in the market. ${ }^{\text {'20 }}$
Having thus defined the test for a finding of coordinated effects, the Tribunal turned to an exposition of the evidence required to come to a conclusion as to the likelihood of coordination or increased coordination. As a point of departure, the Tribunal listed the conditions for coordination already discussed above..$^{21}$ However, the Tribunal stressed that the proffered list should not be taken as a categorical test for the probability of coordination in future merger cases, and that " $[t]$ hese prerequisites are useful therefore, not as a basis for determining what our own legal position on these issues should be, but to help as a method of analysing the theory of harm advanced in this case. ${ }^{\prime 22}$

In this regard, the Tribunal echoes the European CFI decision in Sony/Bertelsman ${ }^{23}$ which cautioned against a dogmatic application of the distilled requirements in stating that question of coordinated effects may:

be established indirectly on the basis of what may be a very mixed series of indicia and items of evidence relating to the signs, manifestation and phenomena inherent in the presence of a collective dominant position.

Turning to whether interlocking directorships between competing firms might be amongst such "indicia and items of evidence" as may raise the probability of coordinated interaction, the Tribunal quoted with authority a number of international sources, ultimately concluding that:

[I]t would seem that cross-directorships provide at least two solutions to the cartel problem. Firstly, they provide a forum for the exchange of information in a setting conducive to an innocuous explanation. Secondly, they provide a highly efficient and expeditious mechanism for monitoring compliance with the terms of the coordination. ${ }^{24}$

Against the theoretical background, the Tribunal turned to the specific facts of the case. The Commission's apparent concern with Anglo's presence on the various boards of the Exarro group should be seen in light of the fact that Anglo competed with Exarro and BHP, (the latter also represented at Exarro holding company level) in the thermal coal market. 
It should also be noted that prior to the merger, BHP and Anglo were represented at the board of Eyesizwe Coal. Thus, any coordinated conduct arising out of the cross-directorships among these competitors was as likely premerger as post. The Commission indeed appeared to be of such a view when it stated in its recommendation that the merger would result in such coordinated market structure being sustained.

In other words, the Commission sought to use the merger as an opportunity to remedy an existing anticompetitive market structure, so that "even if a merger did not of itself lead to a substantial prevention and lessening of competition, if the merger perpetuated or sustained an anticompetitive structure, this was sufficient to justify the imposition of remedial conditions. "25

This approach was rejected by the Tribunal as being contrary to the manner in which the Act should be interpreted; which is that the theory of harm to be proven in this case is whether the merger strengthens any existing coordination, or more colloquially "whether the merger had made a bad situation any worse." 26

Factually speaking, the merger resulted in Anglo reducing its holding in its erstwhile Kumba coal assets. It is also reduced to having only one director at Exarro (as opposed to the five originally appointed when those assets were held by Kumba) and another at the more rarefied level of Eyesizwe SPV. BHP that had also been represented at operating company level, is now relegated to a company two steps removed from operations. ${ }^{27}$

Furthermore, the restructure and spin-offs described above resulted in the creation of a company that, rather than being a dedicated coal company, was now a diversified mineral company. ${ }^{28}$

The Tribunal reasoned that in terms of the coordination of coal, while the erstwhile board of Eyesizwe may have provided a forum for coordination between that company, BHP and Anglo, the removal of BHP to shareholder level, the mineral operations of Exarro being generalised and the reduction in Anglo's economic interest in coal would now reduce the ability and impetus to coordinate.

Accordingly, the Tribunal found that:
[T] he merger does not meet the test required of strengthening the existing coordination. To the contrary, the merger inhibits this possibility, because it complicates the possibilities for the exchange of information and monitoring, and it changes the incentives of all the firms who may have been party to any pre-existing coordination. ${ }^{29}$

Following that the Tribunal's decision does consider further issues related to the matter at hand that are worth mentioning.

In coming to its ultimate conclusion, the Tribunal noted that given the diversified nature of Exarro, "the type of executive who will be appointed to the Exxaro board will need to be a generalist not a coal industry insider. ${ }^{\prime 30}$ The Tribunal considered this nuanced change as indicating that the information flow to (and presumably from) the board would be qualitatively less detailed, immediate and transparent than a company whose sole business is coal. It is perhaps worth pointing out that such an argument, although supportable, is somewhat at odds with the CAC decision in the Momentum case where the CAC impliedly reasoned that the type of individual present at board meetings did not preclude valuable information from being provided to other individuals within a competing organisation who would know what to make of it.

The Tribunal and Commission both appeared preoccupied with the impact of the crossdirectorships on the coal market. However, neither authority raised the question of whether the new structure would allow BHP to gain insight into the iron ore market as result of Exarro's interest in SIOC. Although this issue was not raised, it may have been disposed of in the light of the Tribunal's view that BHP's presence at shareholder level rendered it unable to garner useful information about Exarro's operations further down the corporate chain. ${ }^{31}$

Finally, and perhaps most disconcertingly, the Tribunal expressly reserved its judgment on whether the Commission's point of law that a merger which merely sustains an anti-competitive market structure, rather than worsens it, may be found to be itself anti-competitive under the Act. Although the Tribunal did state that "this has not 
been the manner in which we have interpreted the act this far"; it leaves the door open for a different interpretive approach in making the reservation that it has "not yet been called upon to decide the matter definitively..." This is apparently because looking at the facts, the merger in fact weakened the environment for existing coordination and therefore the question of whether sustained criteria for coordination did not actually arise. ${ }^{32}$

\section{Primedia Ltd, Capricorn Capital Partners} (Pty) Ltd, New Africa Investments Ltd and The Competition Commission and African Media Entertainment Ltd $^{33}$

The Tribunal's approach to cross-holdings was most recently tested in the Primedia case, which originated in the conditional approval of an intermediate merger by the Commission. Although the case ultimately deals with the competitive effects of a cross-holding, it is worth noting that the presence of a Primedia director on the board of a rival was initially the cause of the Commission's consternation, which it sought to remedy by imposing a condition that Primedia waive its right to appoint a director. This condition was not acceptable to Primedia and was appealed to the Tribunal, unleashing the series of decisions to follow. The Tribunal's decision to unconditionally approve the merger was then brought under review to the CAC by African Media Entertainment ("AME"). ${ }^{34}$ The CAC referred the matter back to the Tribunal for a more thorough analysis of the effect of a cross-holding arising out of the merger.

The merger involved the acquisition by Primedia and Capricorn of the entire issued share capital of New Africa Investments Ltd ("NAIL"). Capricorn is a financial services firm and played no part in the competitive analysis. The controversy arose due to the fact that the acquisition of NAIL gave Primedia an effective 18.1 per cent economic interest in a radio station, Kaya FM. At the same time, Primedia controlled a stable of radio assets, which notionally competed with Kaya FM (although the extent of such competition was a source of much debate throughout the proceedings). The key issue which ultimately arose was whether Primedia's so-called passive investment in Kaya
FM would give rise to anti-competitive effects.

In its initial decision, the Tribunal focussed on the question of whether Primedia would have de facto control of Kaya FM and, finding in the negative, treated this as dispositive of the enquiry. The CAC made it clear that the Tribunal was bound to consider the competitive effects of even a non-controlling financial interest arising out of the merger.

The Tribunal's initial view was arguably somewhat in deference to an assumption long held by authors like Areena and Turner, that "a non-controlling interest has no intrinsic effect on competition at all". ${ }^{35}$ The CAC criticised this approach, citing with approval an article by O'Brien and Salop ${ }^{36}$ which suggests that partial acquisitions of ownership can indeed have significant competitive effects. As it was enjoined to do, the Tribunal in its reconsideration of the matter, spent considerable time analysing the O'Brien and Salop thesis.

Where a firm acquires outright control of another, it is self-evident that the merger will have implications for the competitive behaviour of the target firm. O'Brien and Salop ${ }^{37}$ however argue that even the acquisition of a passive interest may alter the incentives of the acquiring firm.

In the first instance, a passive financial interest can render a price increase by the acquiring firm profitable, to the extent that its investment in a rival subsequently allows it to recoup some of the profits lost due to customers at the margin taking their business elsewhere. A share in these increased profits may compensate for the lost business (in this case, the customers in question were advertisers) to the extent that those customers divert to the investee.

This theory thus diverges somewhat from the coordinated effects doctrine generally associated with cross-holdings (and discussed above) as it does not require any conscious cooperation from the target firm, relying purely on the unilateral conduct of the acquirer for a perceived harm to competition. An analysis of this theory of harm requires substantial econometric modelling based inter alia on diversion ratios and the competitive relationship between the acquirer and target. Their relative profitability and pricing histories also need to be considered 
when ascertaining whether indeed the target is likely to capture sufficient business to enhance the net profits of the acquiring firm. In casu, the Tribunal was not satisfied that the evidence supported such a contention. For instance -

- It was not clear that the radio stations controlled by Primedia were direct competitors of Kaya FM to the extent that advertisers who chose to desert Primedia's stations following a price hike would "fall with sufficient reliability into the pockets of Kaya." 38 Furthermore, there was no guarantee that advertisers would not divert to alternative media, such as billboards and print.

- Whilst Primedia enjoyed 100 per cent of the profits in its own stations, it can anticipate less than 19 per cent in respect of Kaya FM. It was not evident that this would be sufficient to compensate for any loss of revenue at Primedia.

- There was no evidence of the relative profitability of Kaya FM and Primedia, which O'Brien and Salop expressly consider as a relevant factor. If Kaya FM's cost base were the higher (which was suggested by the available evidence) the return on any revenue diverted to Kaya FM will be less than that enjoyed by Primedia directly.

- As Primedia was unable to control the board of Kaya FM, there was no guarantee that any increase in profits would find its way to shareholders rather than be reinvested into the business. Paradoxically, such reinvestment could be used to more effectively target Primedia, thus increasing the potential loss of revenue beyond mere diversion at the margin.

Ultimately, the Tribunal was unable to root in commercial reality the theory that Primedia would raise prices, confident of the notion that what it loses to rivals it will gain back in a share of Kaya's earnings.

However, the further theory posited by O'Brien and Salop, which was considered by the Tribunal, is based on coordinated effects. Essentially, if Primedia and Kaya FM both increased prices, thus rendering Kaya FM a less attractive alternative, customers may elect to bear with Primedia rather than divert to Kaya FM. ${ }^{39}$

O'Brien and Salop refer to this alternative theory as "Coasian joint control" and requires the management of each firm to align their strategies to maximise the joint profits of both - in other words, they behave as if they had merged. The theory is another in a litany of propositions to overcome the "cartel problem" discussed above. Like most theories of coordination, the fly in the ointment is the presence of transaction costs, which tend to override joint incentives to cooperate and are manifest in the "unilateral incentives to deviate from the cooperative outcome to maximise independent profits" ${ }^{40}$ - that is, to cheat by secretly cutting prices.

Applied to the facts of the present case, Primedia has the incentive, notwithstanding its "promise" to raise prices to the cooperative (or merger equivalent) level, to secretly cut prices to maximise its profits at the expense of the target firm. "After all," point out O'Brien and Salop, "the owner has a 100 per cent stake in the acquiring firm but only a partial interest in the acquired firm. " ${ }^{41}$ Moreover, the management of Kaya FM have a similar dilemma: one of its shareholders, Primedia (through NAIL) wants it to cooperate, while the remaining shareholders want it to cheat by cutting prices (all the more so given that Kaya FM does not only compete with Primedia). As O'Brien and Salop concede "both types of transaction costs may prevent the Coasian outcome from being achieved." ${ }^{\prime 2}$

Recalling the Kumba Resources case, the Tribunal reiterated that coordinated effects can arise either where an existing coordination is strengthened (requiring evidence of coordination and the merger's propensity to strengthen it), or where coordination becomes probable as a result of the merger.

In the present case, a third player in the radio industry, Kagiso Media Investments ("Kagiso") also had an existing passive financial interest in Kaya FM. In the first instance, the Tribunal found that there was no evidence to conclude that Primedia had previously coordinated prices with Kaya FM. There was also no evidence to support an allegation that Primedia and Kagiso had engaged in past coordination. 
Accordingly, the analysis turned to whether the acquisition by Primedia of a non-controlling stake in Kaya FM could increase the likelihood of coordination.

Simply put, if the merger allows Primedia, Kaya FM and Kagiso to coordinate a joint increase in advertising rates, the advertising split between the respective radio stations might remain stable, as the stations would remain as attractive to advertisers relative to one another.

The objectors to the merger further argued that the presence of a Primedia director on the board of Kaya FM would be the key factor in cementing the coordination, providing the opportunity to exchange pricing information and monitor cheating.

The Tribunal ultimately found that while "the possibility of co-ordination to exist post transaction exists as a theoretical possibility... in order to make the case... the evidence needed to be stronger than the mere holding of an interest in a rival and the right to appoint a director to its board... As a result the theory is dependent on making a number of assumptions all of which are premised on shaky foundations" ${ }^{\star 3}$. Among the assumption disregarded by the Tribunal were the following -

- It was not clear that price coordination would result in stable custom from advertisers. On the contrary, the clear differentiation between the stations (as to target market, content and listenership) concerned could result in advertisers continuing to support some over others.

- It was not shown that it would in fact not be more profitable for the rival stations to compete for market share, particularly visà-vis Primedia, which had the most lucrative share of the market.

- It was questionable whether the information that may be gleaned by the presence of a director appointed by Primedia would be particularly valuable. The aggregated way in which management tends to present these matters to boards should be considered, as well as the fact that pricing information could not come through other means (such as advertising agencies).
- The absence of reciprocity also posed a problem, in that Kaya FM had no concomitant right to a board member at Primedia in order to monitor its compliance with any proposed coordination. This would impact on Kaya's incentive to coordinate.

- The convoluted structure of control involved certain additional shareholders that had no competing assets and who would have nothing to gain from becoming complicit in a coordination strategy and indeed, may prefer a competitive outlook. This lack of alignment of shareholder interests would also make it difficult for management to implement the coordination, which is the tenet of coasian joint control.

- There was no evidence that Primedia as the acquiring firm was an industry maverick, whereby it may be discouraged from continuing to compete aggressively because of the effect this may have on the target investment. ${ }^{44}$

Despite the detailed analysis conducted by the Tribunal in the light of the CAC decision and the latter's regard for the O'Brien and Salop thesis, it is worth noting that in a detailed post-script, the Tribunal is at pains to express its reservations about such an approach.

The Tribunal noted that the Competition Act defines a merger with regard to the establishment of control. As the Tribunal ruled that Primedia did not control Kaya FM, the anomaly had arisen that had Primedia acquired the stake in Kaya FM directly, rather than through Nail. This means the transaction would not have required notification and the analysis that had taken all of two years would not have taken place at all. In a dictum as close as the Tribunal has ever come to expressly disagreeing with the CAC, the Tribunal states -

Does this mean that passive investments by way of secondary acquisition would not be capable of adjudication even though economic theory suggests that there may be instances of anticompetitive effects? Yes, that is what it means. ${ }^{45}$

The Tribunal questioned the applicability of the much vaunted O'Brien and Salop to South 
Africa's control-based merger notification regime, pointing out that the authors write in the context of the US law, which does not impose a requirement of control in order for an acquisition to be notified. ${ }^{46}$

European merger regulation, like in South Africa, is triggered by a change of control. The Tribunal summarised a number of writers' conclusions that while passive financial investment can give rise to anticompetitive effects, "there is also an acknowledgement that these issues are not subject to present merger analysis premised as it is on notions of control." $" 47$

The Tribunal concludes this line of reasoning by expressing concern at the notion that a full-blown competitive assessment should be undertaken in each merger notification in which passive, non-controlling investments are embedded. Amongst other things, the Tribunal questions the capacity of the merger control system to contend with lengthy enquiries in regard to the subtle competitive effects of passive investments, given the fact that anticompetitive effects are rare. The Tribunal's position is best summarised in its own words -

That anticompetitive effects may arise out of transactions that fall short of control we recognise as theoretically sound, but it does not form part of our merger review regime which has control as its centre piece. ${ }^{48}$

Should this apparent blockade be lifted, following a clarification from the Tribunal or an unequivocal ruling from the CAC, the Primedia case sets a clear precedent for the type of evidence that will be required to assess the competitive effects of a non-controlling crossholding.

\section{5}

\section{In conclusion}

It is clear that the competition authorities' approach to cross-holdings and cross directorships has developed considerably in the level and sophistication of analysis. The case law has shown a certain evolution of approach from somewhat knee-jerk suspicion to a more reasoned and, perhaps, circumspect approach to the question of cross-shareholdings. Tribunal has by now adopted an approach that demands evidence of likely coordination, which has come through in recent decisions. ${ }^{49}$

The analysis may well have reached its zenith in the Primedia triptych, with its careful study of economic theory and international jurisprudence. However, the ultimate impact of the Primedia case on the approach of the authorities to passive investments may be limited as, rather disconcertingly, the Tribunal ultimately pulls the rug out from under the proponents of such enquiries, by arguing that they have no place in merger analysis under South Africa law. If this is indeed the case, then it seems as if the opportunity to consider the competitive impact of cross-holdings will only apply where such cross-holdings amount to control in each case (per the Momentum Life case). In such an event, the analysis will differ substantially from that posited by O'Brien and Salop and, it must be said, the CAC.

From a coordinated effects point of view, there is some recourse in section 4(2) of the Competition Act, which presumes an agreement to fix prices where firms have substantial shareholdings in one another. However, the possible unilateral effect of a passive investment seems, for the time being, to be of academic interest only.

\section{Endnotes}

1 A version of this paper was initially presented at the $1^{\text {st }}$ Annual Competition Commission, Competition Tribunal and Mandela Institute Conference on Competition Law, Economics and Policy in South Africa - 21 May 2007

2 In the EU, coordinated effects are sometimes also referred to as giving rise to "joint dominance" while unilateral effects relate to "single firm dominance".

3 Certainly, that is the overwhelming concern with horizontal mergers (ie, those involving competitors). In the case of vertical or conglomerate mergers, others factors will be important, such as the levels of possible foreclosure, although it can be said that the ultimate question remains as to whether such factors will eventually result in increased market power, which in simple terms ought to translate into increased market share. 
4 Indeed, it may be interesting to note that in those cases where an argument for coordinated effects was advanced and eventually rejected, there was a marked absence of alleged unilateral effects. This could indicate that coordinated effects are more likely to raise concern in conjunction with unilateral effects, rather than in isolation.

5 These conditions were set out by the EU Court of First Instance in the Airtours case (Case T-342/99)

6 See M Motta (2004), Competition Policy Theory and Practice page 421 for a detailed list of structural factors which may come into play.

7 Op cit pg 144

8 This provision is not particularly well drafted and it has yet to be relied upon by the competition authorities in prosecuting an alleged cartel. However, the Tribunal has on a number of occasions sought to highlight the section as indicating a broader legislative purpose extending to merger analysis.

9 Tribunal Case no 87/LM/Sep05

10 Paragraph 37 of the judgement

11 As indicated by the Tribunal's statement at paragraph 42 that "given the size of the First Rand group and its abundance of executive talent, it can presumably find other suitable directors to replace those to the board the present incumbents elect to resign from."

12 Case no 58/CAC/Dec05

13 Paragraph 13

14 Case no 14/LM/Feb06

15 As to 66 per cent. Anglo also appointed 5 directors out of a total of 15

16 Main Street 333 (Pty) Ltd or "BEE Holdco"

17 It was suggested that Anglo had in no small measure staked its reputation on the success of Exarro and its association with it, particularly on the board, was required to give the new company credibility. To a lesser extent, BHP remained involved for similar reasons.

18 Thermal or steam coal is used in power generation

19 Separately from Kumba, although, for the purposes of analysing unilateral effects, the authorities correctly treated Kumba and Anglo as a single economic entity

20 As emphasised and edited by the Tribunal in paragraph 38 of the judgment

21 I.e. conditions that allow would-be coordinators to monitor one another's adherence to the coordination and punish deviation within a market in which coordination is feasible, such as an oligopoly with high entry barriers.

22 At paragraph 42. It does strike one that such an observation, at least in part, may be designed to pre-empt any criticism, previously levelled at the Tribunal, of slavishly applying foreign jurisprudence.

23 Independent Music Publishers and Labels Association (Impala) v European Commission, judgment of 13 July 2006 - Case number T-464/04

24 At paragraph 48

25 At paragraph 54

26 This shows a marked departure from the view taken by the Tribunal in the first Momentum case above

27 This is in keeping with the CAC decision in Momentum, which viewed interlocks at holding company level more benign than at operational level.

28 Of an enterprise value of R24 billion, the coal assets represented only R1.6 billion. By comparison, Exarro's 20 per cent interest in SIOC was worth 3.8 billion.

29 Paragraph 78

30 Paragraph 69

31 Indeed, at paragraph 67 the Tribunal stated that the relegation of BHP was "probably the most significant fact in the merger."

32 See paragraphs 55 and 56

33 Case no 39/AM/May06. See also the CAC decision, Case no 68/CAC/MAR/07

34 This case is also significant for confirming the right of an intervenor in merger proceedings to bring a review application against the ruling of the Tribunal.

35 See Phillip Areeda and Donald Turner, Antitrust Law (1980) at 322, cited at paragraph 53 of the CAC decision. In fairness, the Tribunal has clarified Areeda and Turner's view as relating not to the absence of a competitive threat arising our of partial holdings, but rather to fact that the nature of the threat is fundamentally different to when two independent firms become subject to a single controlling mind. Whilst the latter poses an inherent threat to competition, the former is more difficult to quantify.

36 Daniel O'Brien and Steven Salop, “Competitive Effects of Partial Ownership: Financial Interest and Corporate Control", Antitrust Law Journal, Volume 67, 2000, page 559 .

37 The authors furthermore posit a modification of the Herfindahl-Hirschman Index (MHHI) to measure the effects of a passive investment with reference to the structure of the market in which the target and acquirer participate. Essentially, the post merger change in concentration (delta) for a passive investment is measured by multiplying the respective market shares of the acquiring and 
target firms by the percentage economic interest that the acquiring firm has in the target.

38 See at paragraph 84 of the Tribunal decision where an existing wide discrepancy in rates was seen as evidence that Kaya did not, pre-merger, act as a competitive restraint on Primedia and was therefore unlikely to be the next best substitute for advertisers.

39 Note that this theory still requires Kaya FM to be the next best substitute in comparison to other available outlets, which the intervenors were unable to convincingly indicate.

40 O'Brien, supra, page 582, quoted by the Tribunal at paragraph 26.

41 Ibid

42 Ibid
43 See paragraph 120 of the Tribunal decision

44 This observation is largely on all fours with Motta's views quoted (Motta, 2004:144)

45 See paragraph 143 of the Tribunal judgement.

46 The Tribunal as well as O'Brien and Salop note that section 7 of the Clayton Act covers the acquisition of any part of a company's stock where the effect may be to lessen competition.

47 See paragraph 15 of the Tribunal decision.

48 At paragraph 164 of the Tribunal decision.

49 This puts the South African authorities someway behind the US, where cross-directorships may be per se prohibited, and not even as far as commentators like Motta, who show an a priori distrust with cross-holdings. 